\title{
Policy Direction on Driving Population for com conter Reducing Poverty in the West Sumatra Province
}

\author{
Teguh Widodo, Iswandi Umar, Ramadhani, Suhatman
}

\begin{abstract}
Reducing poverty is always to become the target of every country and regional leader in each campaign. The efforts are made in many ways, but the programs in the form of providing basic needs assistance, productive economic efforts, and so on. Unfortunately, interventions are to address visible symptoms but not to solve the root of the problems or causes. That is because the cause of poverty is not so excavated so that until now the percentage of the poor always fluctuates. This research tries to see in terms of the number of children (TFR) that may have contributed to the percentage of poor people in West Sumatra. The research method uses linear regression analysis using secondary data from Susenas 2019. To determine policy direction using Interpretative Structural Modeling (ISM) analysis. The ISM analysis involved 15 relevant stakeholders from interested institutions. The results showed that TFR contributed 34.4 percent to poverty in the research area. As a direction of population control policy to reduce poverty, that is the expansion of access to contraceptives and delay of marriage age.
\end{abstract}

Keywords: Policy Direction, Population Identification, Poverty.

\section{INTRODUCTION}

$\mathbf{P}_{\text {overty alleviation is often intervened symptomatically }}$ to the poor so that it has not been resolved yet. Poverty's cause is multi-factorial. The causes of it for each individual are different and unique [1,2], but unfortunately, the interventions carried out are general, tend to be uniform, and especially in Indonesia is often politically charged. Perspectives on the causes of poverty are often viewed as an inability to full fill the basic needs due to a defect, limited education, and inability to compete in fieldwork; limited skills, or even because of laziness factor.

The forgotten perspective is that poverty occurs because of the high dependency rate. Many people in productive age have to bear the burden of their members who are not working either under 15 or over 60 years old. The age of dependence under 15 is mostly, due to the number of women

Manuscript received on May 23, 2021

Revised Manuscript received on May 31, 2021.

Manuscript published on June 30, 2021.

* Correspondence Author

Tegus Widodo*, Agency of National Family Planning Population (BKKBN) West Sumatra Province - Indonesia. Email: t29uhw@yahoo.co.id

Iswandi Umar, Department of Geography and Doctoral Program of Environmental Science, Universitas Negeri Padang - Indonesia. Email: iswandi_u@yahoo.com

Ramadhani, STIE West Sumatra - Indonesia. Email: rahmadhani@gmail.com

Suhatman, Doctoral Program in Development and Environmental Economics - Universitas Negeri Padang and STIE West Sumatra Indonesia, Indonesia. Email: suhatman@gmail.com

(C) The Authors. Published by Blue Eyes Intelligence Engineering and Sciences Publication (BEIESP). This is an open access article under the CC BY-NC-ND license (http://creativecommons.org/licenses/by-nc-nd/4.0/) who give birth or in demographic jargon better known as TFR. So it is likely that the influence of TFR in a region will affect the percentage of poverty of its inhabitants.

The based on the experience of countries such as China and others that can suppress the birth rate and increase the productivity of the population in productive age can increase per-capita income. Recently China is to be a respected country by other superpowers. By decreasing birth and mortality rates, it turns out that countries may earn demographic bonuses - and the bonus may only be enjoyed once in the way the age of the country. Demographic bonus is also a momentum to determine the progress point of the nation.

According to this condition, it is important to examine the possible influence between poverty and fertility in a region, in this context is West Sumatra. The West Sumatra chosen as a locus is logically based on the changes in the structure of the age group that is currently shifting from increasing the TFR from 2.5 in 2017 (SDKI;2017)to 2.75 in 2019 (SUSENAS;2019). The based on previous research conducted by [3] where he had conducted throughout Indonesia, it pointed out that there is much correlation between TFR and poverty.

\section{METHODS}

The locus research is in the West Sumatra Province. It consists of 19 regencies/cities. The center of government is in the city of Padang. It was conducted for four months from January to April 2021.
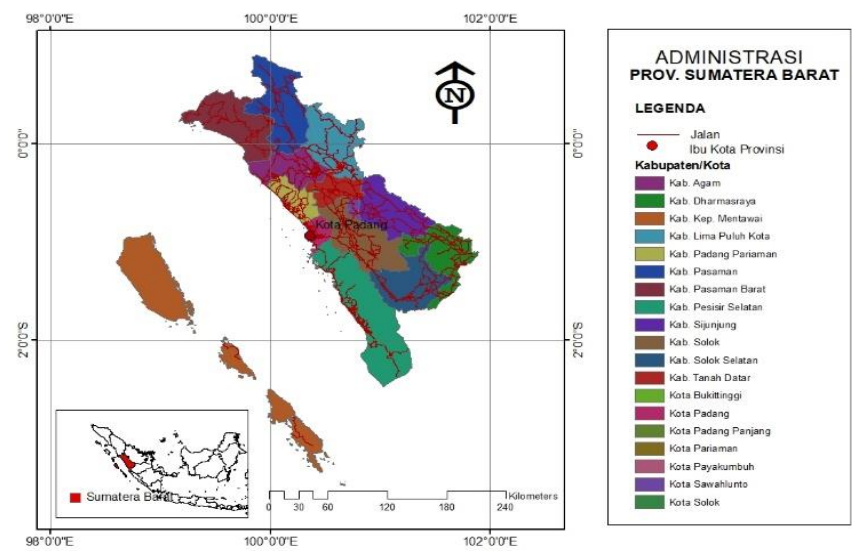

Fig. 1.The research locus

This research is quantitative inferential. The data is a cross-section. It is obtained secondary by utilizing poverty data of West Sumatra 2019 from the Central Bureau of Statistics (BPS).

Published By:

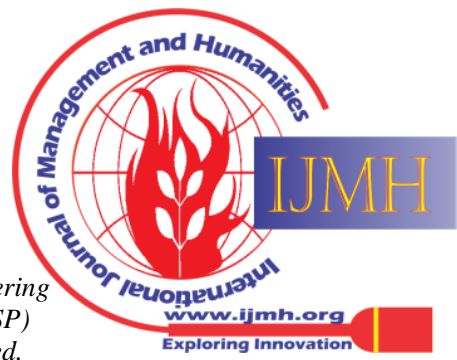


While TFR West Sumatra is taken from the results of the Economic and Social Survey (SUSENAS;2019). The two data are regressed by using SPSS ver.16 application. Before regression, a classic assumption test (normality test, linearity test, and heteroscedasticity test) is conducted to determine the validity requirements of a simple linear regression test. The variable dependent in this case is the percentage of poverty while the Independent variable is the TFR.

To define the policy direction, it uses the ISM method. According to [4] stated that ISM method is very effective to structure very complex problems, explain problems, and determine causal relationships. In determining the contextual relationship between elements is determined based on expert opinion. Experts involved in determining the contextual relationship of elements come from relevant stakeholders, namely: 1) The Center for Population and Environmental Research (PPKLH) UNP; 2) Population Members; 3) Non-Governmental Organizations (NGOs); 4) BKKBN of West Sumatra Province; and 5) Community Leaders. The number of experts involved in determining policy direction as many as 20 people. Some considerations in determining research experts are 1 ) having experience with the field of study; 2) have a reputation or competence with the field studied, and 3) have high credibility in the areas studied.

According to [5] there are broadly several steps in the ISM method, such as 1) parsing elements into several sub-elements;2) establish a contextual relationship between sub-elements;3) determine the Structural Self Interaction Matrix (SSIM); 4) the creation of the Reachability Matrix (RM); 5) transitivity; 6) define the hierarchy structure vertically; and 7) determine the matrix relationship of Driver Power (DP) and Dependence (D). To create a matrix of interaction SSIM (Structural Self Interaction Matrix) is done using comparison in pairs with the symbol VAXO. Where the symbol has meaning is:
- $\mathrm{V}$ if Eij = 1 and Eji = 0; V = sub element to $\mathrm{i}$ is more instrumental than sub element to $j$ and not vice versa

- $\mathrm{A}$ if $\mathrm{Eij}=0$ and $\mathrm{Eji}=1 ; \mathrm{A}=$ sub element to $\mathrm{j}$ is more instrumental than sub element to $\mathrm{i}$ and not vice versa

- $\quad \mathrm{X}$ if Eij = 1 and Eji = 1; X = both sub-elements have the same role level values and are interrelated, and.

- $\mathrm{O}$ if Eij = 0 and Eji = 0; $\mathrm{O}=$ the two sub-elements are not interrelated

Furthermore, [6, 5] classified the relationship of elements into four categories, namely:

- The First Quadrant is called autonomous, which consists of sub-elements that have a driver power value (DP) $\leq 0.5$ $\mathrm{X}$ and a dependence value (D) $\leq 0.5 \mathrm{X}$. Where $\mathrm{X}$ is the number of sub-elements in each element. Sub elements that are in the first quadrant can be interpreted that the sub-element is not related/small relationship with the system.

- The Second Quadrant is called dependent, consisting of a sub-element that has a driver power value (DP) $\leq 0.5 \mathrm{X}$ and a dependence value (D) $\geq 0.5 \mathrm{X}$. This sub-element that is in the second quadrant is a sub-element that depends on the element in the third quadrant.

- Quadrant III: hooks (Linkage) it consists of sub-elements that have a driver power value (DP) $\geq 0.5 \mathrm{X}$ and a dependence value $(\mathrm{D}) \geq 0.5 \mathrm{X}$. Where $\mathrm{X}$ is the number of sub-elements in each element. The sub-elements that come in this quadrant III need to be checking carefully because each action on one sub-element will affect other sub-elements located in quadrants II and IV.

- Quadrant IV: Drive (Independent) consists of sub-elements that have a driver power value (DP) $\geq 0.5 \mathrm{X}$ and a dependence value (D) $\leq 0.5 \mathrm{X}$. Where $\mathrm{X}$ is the number of sub-elements in each element.

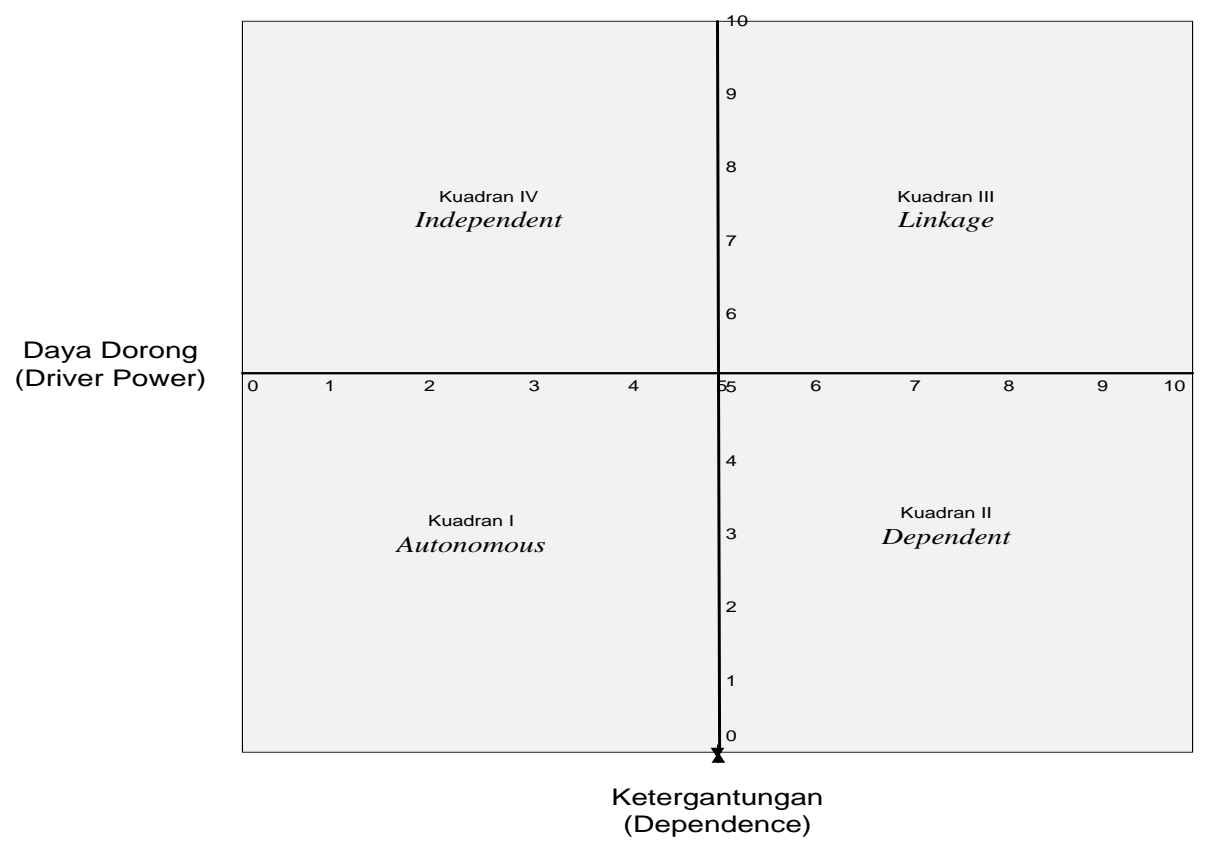

Fig. 2.Matriks driver power and dependence on ISM

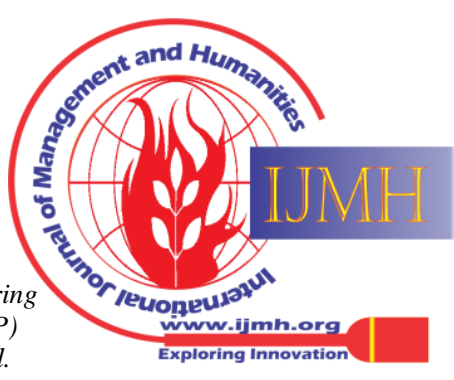




\section{RESULTS}

Before conducting a hypothesis test, firstly, it is conducted normality test. According to [7] normality testing was conducted to find out the variable distribution patterns that support each test variable of one Sample Kolmogorov
Smirnov Test. In normal testing, each research variable is determined from the value of Asymp Sig (2-tailed) above 0.05. Based on the results of the tests that have been conducted obtained a summary of the results seen in Table 1 below.

Table- I: The results of the normality test

\begin{tabular}{|l|l|r|}
\hline \multicolumn{2}{|c|}{ One-Sample Kolmogorov-Smirnov Test } \\
\hline \multicolumn{2}{|c|}{} & Unstandardized Residual \\
\hline $\mathrm{N}$ & Mean & 0 \\
\cline { 2 - 3 } \multirow{2}{*}{ Normal Parameters ${ }^{\mathrm{a}}$} & Std. Deviation & 1.9474736 \\
\hline \multirow{3}{*}{ Most Extreme Differences } & Absolute & 0.132 \\
\cline { 2 - 3 } & Positive & 0.132 \\
\cline { 2 - 3 } & Negative & -0.13 \\
\hline Kolmogorov-Smirnov Z & & 0.592 \\
\hline Asymp. Sig. (2-tailed) & 0.875 \\
\hline
\end{tabular}

Source: Data Processing Results SPSS ver.16

Table 3 shows that the Asymp Sig (2-tailed) value is $0.875>$ alpha 0.05 . So it can be concluded that all research variables used in this study have been distributed normally. So the data processing process can be continued to the next stage.

Simple linear regression analysis is useful for analyzing the linear relationship between one independent variableand one dependent variable. Table 4 above, can be seen the value of constants and coefficients regression of the variable TFR so that the linear equation can be written as follows:

$$
\mathrm{Y}=-6,646+4,630 \mathrm{X}+\varepsilon
$$

The equation above can interpret that:

1) The constant negative value $(-6,646)$ states that assuming the absence of variable $\mathrm{X}$ (TFR),poverty tends to decrease.

2) The coefficient of variable regression $X$ (TFR) is positive $(4,630)$ stating that if the TFR increases by 1 unit it will increase the amount of poverty by 1 x 4,630 $=4,630$, and if otherwise, the TFR value decreases by 1 unit it will decrease the amount of poverty by the same value.

Table-II: Simple linear regression test coefficients'

\begin{tabular}{|c|c|c|c|c|c|c|}
\hline & \multirow[t]{2}{*}{ Model } & \multicolumn{2}{|c|}{$\begin{array}{l}\text { Unstandardized } \\
\text { Coefficients }\end{array}$} & \multirow{2}{*}{$\begin{array}{c}\text { Standardized Coefficients } \\
\text { Beta }\end{array}$} & \multirow[t]{2}{*}{$\mathbf{t}$} & \multirow[t]{2}{*}{ Sig. } \\
\hline & & $\mathbf{B}$ & Std. Error & & & \\
\hline \multirow[t]{2}{*}{1} & (Constant) & -6.646 & 4.038 & & -1.646 & .117 \\
\hline & TFR & 4.630 & 1.426 & .608 & 3.247 & .004 \\
\hline \multicolumn{4}{|c|}{ Dependent Variable: Poverty } & & & \\
\hline
\end{tabular}

Source: Data Processing Results SPSS ver.16

The coefficient of determination is used to determine how big the influence a free variable has on its bound variable [8]. The value of the coefficient of determination is determined by the adjusted value of $\mathrm{R}$ square. The TFR contribution to poverty was 0.334 . This means that $34.4 \%$ of poverty is affected by TFR while the remaining $65.6 \%$ of poverty is influenced by other variables that were not investigated in this research. Through Table 4 above it can be seen that the TFR significance value is 0.004 , small of the set value of 0.05 . So it can be interpreted that there is a significant influence between the TFR on poverty.

Table-III: Model Summary ${ }^{b}$

\begin{tabular}{|c|c|c|c|c|}
\hline Model & $\mathbf{R}$ & $\begin{array}{c}\mathbf{R} \\
\text { Square }\end{array}$ & $\begin{array}{c}\text { Adjusted } \\
\mathbf{R} \\
\text { Square }\end{array}$ & $\begin{array}{c}\text { Std. Error of } \\
\text { the Estimate }\end{array}$ \\
\hline 1 & $.608^{\mathrm{a}}$ & 0.369 & 0.334 & 2.00084 \\
\hline a. Predictors: (Constant), TFR & \\
\hline
\end{tabular}


In the results of the research, it has been explained that there is a positive and significant relationship between TFR to poverty. Therefore, there needs to be policy direction to control the population's recovery. One method that can solve problems that have complexity is the ISM approach. To obtain policy direction in population control to reduce poverty in West Sumatra, Focus Group Discussion (FGD) is conducted by involving stakeholders.
Based on the FGD with experts, there are eight sub elements, namely:

E1. The maturity of the marital age

E2. Reproductive health

E3. Population education through population alert schools

E4. Cross-sectoral cooperation

E5. Movement of contraceptive insertion

E6. Unmetneed drop

E7. Family counseling is "enough for two children"

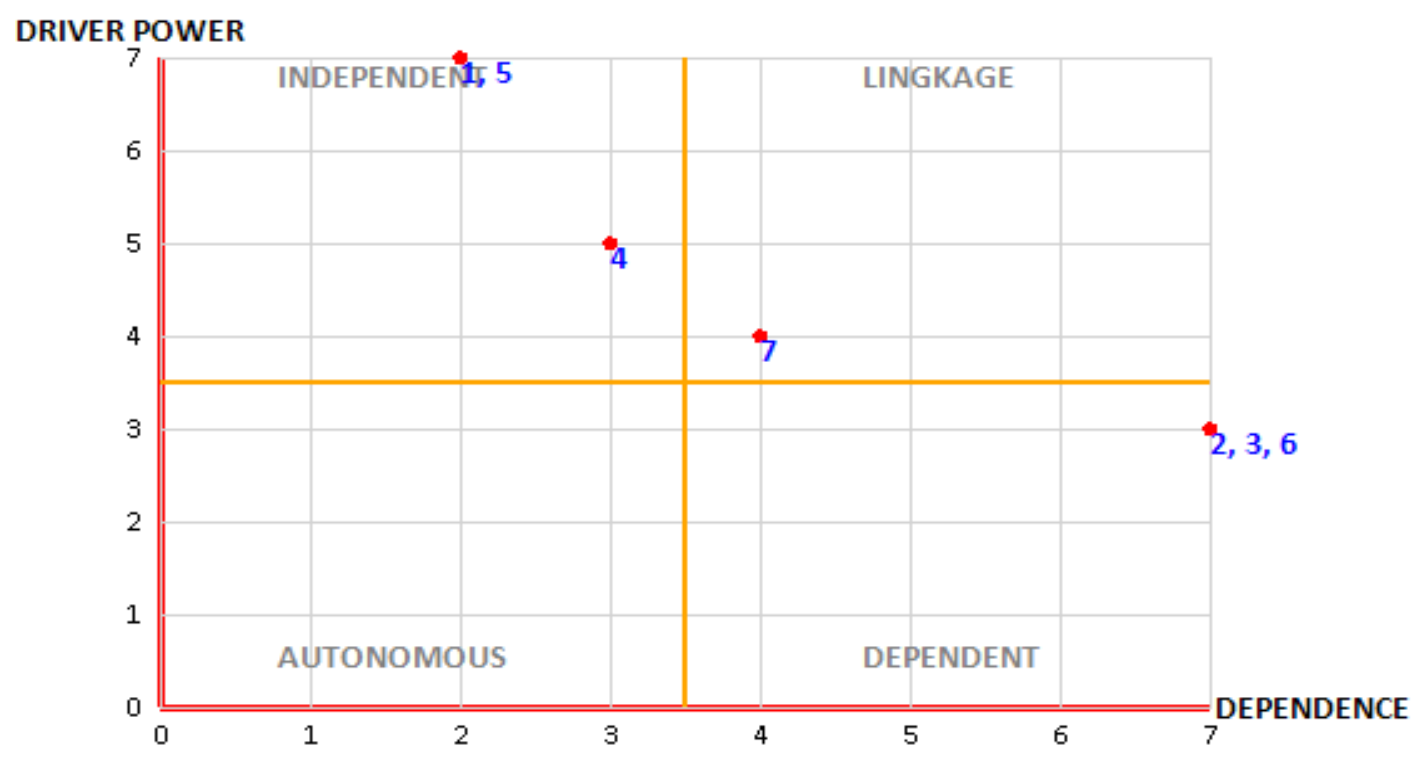

Fig. 3.The sub-element grouping diagram of the population control policy direction

Fig. 3 is a grouping diagram of sub-elements of population control policy direction to reduce poverty in West Sumatra Province. The based on the diagram, there is a high thrust and low dependency or called Quadrant independent. The three sub-elements are sub-element E1 (matrimonial age maturity), sub-element E5 (movement of contraceptive installation), and sub-element E4 (cross-sectoral cooperation). Furthermore, there is one sub-element (E7) which is a linkage category, where the linkage sub-element has a large thrust but has a high dependency there are other elements. In addition, there are three dependent sub-elements, namely sub-elements E2, E3, and E6. Dependent sub-elements have a high dependency on other elements and little thrust.

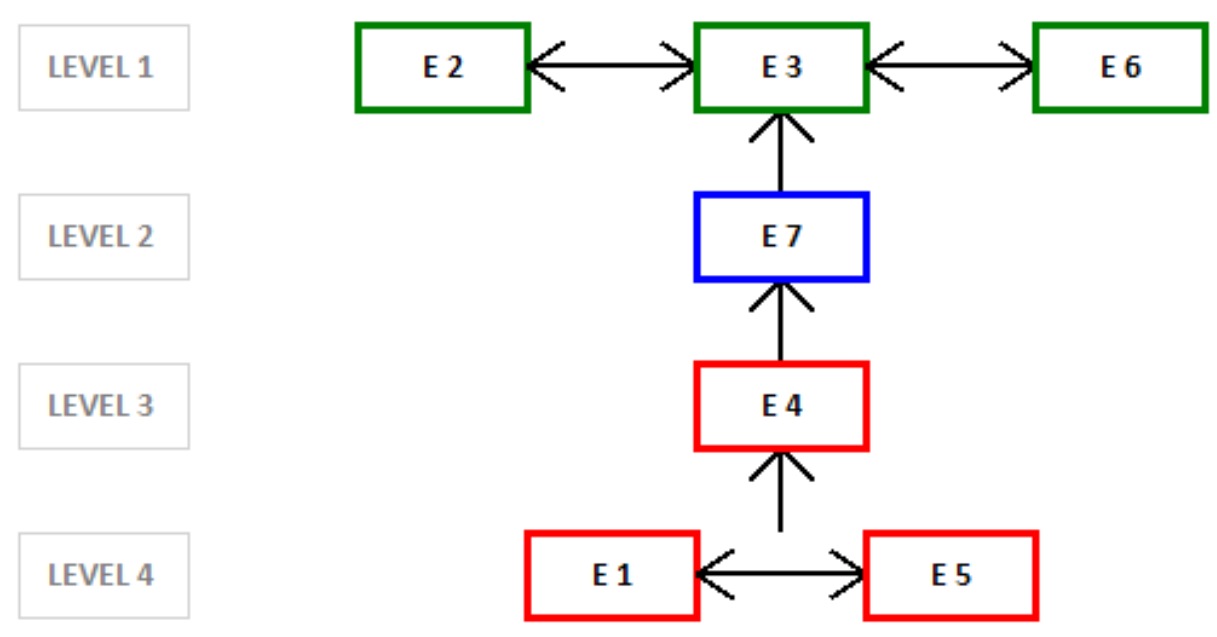

Fig. 4.Hierarchy model of sub-element in policy direction for driving population

Based on analysis of ISM there are four levels of priority scale as a direction of population control policy in West Sumatra Province. For the main priority in population control in the research area, there are two sub-elements, namely the maturity of marital age and the movement of contraceptive installation.

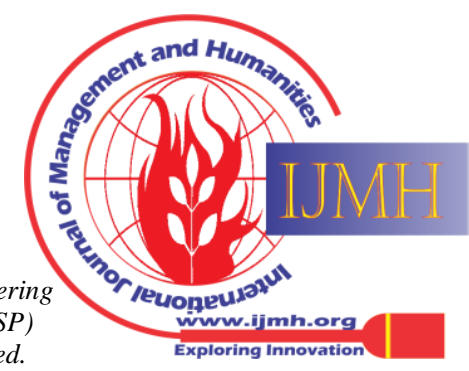




\section{CONCLUSION}

The proofing research problem states that the high influence of TFR is $33.4 \%$ in poverty alleviation. There is $66,6 \%$ poverty caused by other factors. It may be education, disaster, incompetency etc. The policy direction to control the population in order the government can provide access widely to the public so that they obtain contraception easily especially to the fertile spouse. Indeed, it will get challenges from various parties because of the influence of a strong cultural order where Minangkabau community are more religius than other community. They believe that usage of contraception is contradicting with their religion.

\section{ACKNOWLEDGMENT}

It is optional. The preferred spelling of the word "acknowledgment" in American English is without an "e" after the "g." Use the singular heading even if you have many acknowledgments. Avoid expressions such as "One of us (S.B.A.) would like to thank ... ." Instead, write "F. A. Author thanks "Sponsor and financial support acknowledgments are placed in the unnumbered footnote on the first page.

\section{REFERENCES}

1. D.O. Ajakaiye, and V.A. Adeyeye. Concepts, measurement and causes of poverty. Central Bank of Nigeria Economic and Financial Review. 2001. 39(4). p.8-44.

2. O.W. Olowa. Concept, measurement and causes of poverty: Nigeria in perspective. American Journal of Economics. 2012. 2(1). p.25-36.

3. T. Widodo. Apakah Kemiskinan Berkorelasi dengan Fertilitas? Bunga Rampai Program KeluargaBerencana dan Pembangunan Keluarga. IPB Press Bogor. 2020.

4. Eriyatno. System science. Gunawidya, Jakarta. 2013.

5. Marimin. Teori dan Aplikasi Sistem Pakar dalam Teknologi Manajerial. Bogor: IPB Press. 2005.

6. Eriyatno. Ilmu Sistem: Meningkatkan Mutu dan Efektivitas Manajemen. Jilid I Edisi. Ketiga. Bogor: Institut Pertanian Bogor. 2003.

7. D. N. J. Arum, and Anie. Statistik deskriptif \& regresi linier berganda dengan SPSS. 2012.

8. Suhatman, M.R. Sari, P. Nagara, and N. Nasfi. Pengaruh Atribut Produk dan Promosi Terhadap Minat Beli Konsumen Kota Pariaman di Toko Online Shopee. Jurnal Bisnis, Manajemen, dan Ekonomi, 2020 1(2), 26-41.

\section{AUTHORS PROFILE}

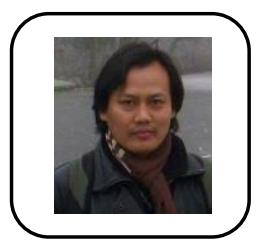

Teguh Widodo, is a researcher on population and social issues at the Agency of National Family Planning Population (BKKBN) West Sumatra Province - Indonesia

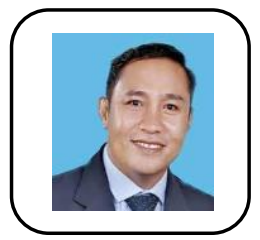

Iswandi Umar, is an associate professor of Environmental Science and actively involved in any researches consider to environmental science, and geography. He is chair of the Masters Program of Geography Education, Universitas Negeri Padang, Indonesia.

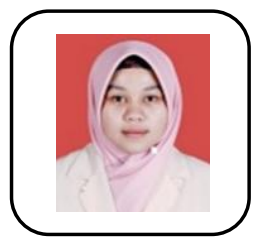

Rahmadhani, is a lecturer of management in STIE West Sumatra - Indonesia and actively involved in any researches regarded to environmental science and management.

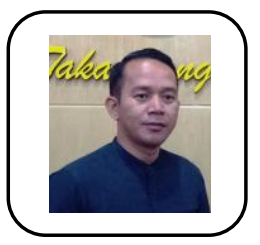

Suhatman, is a student of Doctoral Program in Development and Environmental Economics Universitas Negeri Padang and lecturer STIE West Sumatra - Indonesia, Indonesia

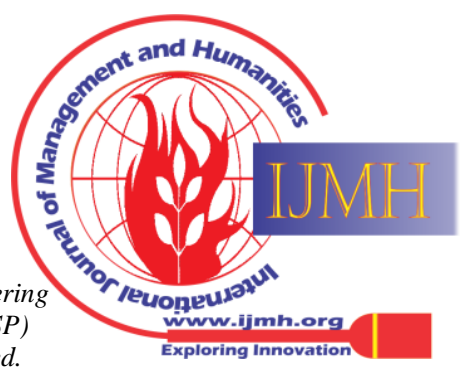

